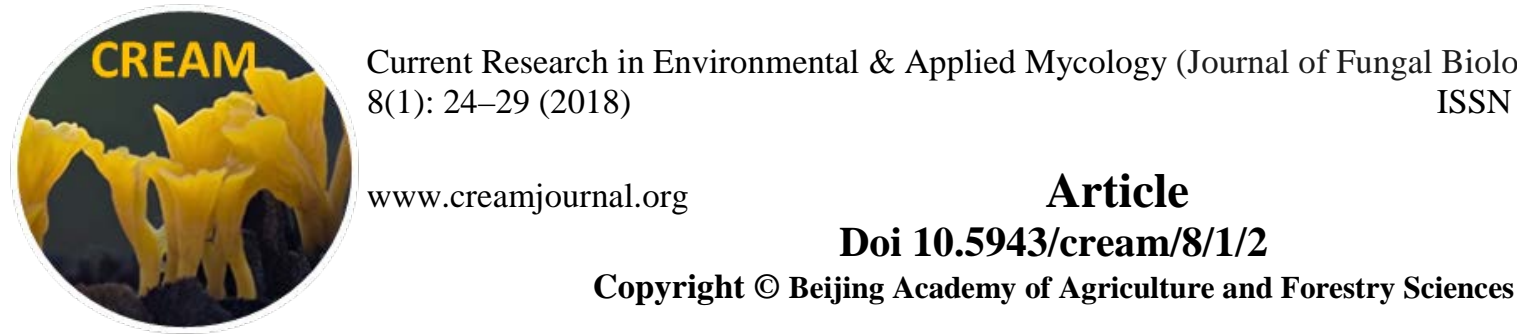

\title{
Discovery of Russula rubropunctatissima in Brazil
}

\author{
Sá MCA ${ }^{1}$, Coimbra VRM ${ }^{2}$ and Wartchow $\mathbf{F}^{3}$
}

\begin{abstract}
${ }^{1}$ Universidade Federal do Rio Grande do Norte, Programa de Pós-Graduação em Sistemática e Evolução, Campus Universitário, Lagoa Nova, CEP 59072-970 Natal, RN, BRAZIL

${ }^{2}$ Universidade Federal de Pernambuco, Programa de Pós-Graduação em Biologia de Fungos, Av. Prof. Nelson Chaves, $s / n^{\circ}$, CEP: 50670-901, Recife, PE, BRAZIL

${ }^{3}$ Universidade Federal da Paraíba, Departamento de Sistemática e Ecologia/CCEN, CEP: 58051-970, João Pessoa, $P B, B R A Z I L$
\end{abstract}

Sá MCA, Coimbra VRM, Wartchow F 2018 - Discovery of Russula rubropunctatissima in Brazil. Current Research in Environmental \& Applied Mycology (Journal of Fungal Biology) 8(1), 24-29, Doi 10.5943/cream/8/1/2

\begin{abstract}
Russula rubropunctatrissima (Russulaceae), a species described from French Guiana, was collected for the first time in Northeast Brazil. It is characterized mostly by the reddish brown pileus, granules on the pileus and stipe and the small basidiospores 4.6-6.1 $\times(4.1-) 5.1-5.6 \mu \mathrm{m}$, that differ from the purplish-lilaceous species of the subsection Pluviales.
\end{abstract}

Key words - Agaricomycetes - Basidiomycota - Neotropic - Russulales - taxonomy

\section{Introduction}

Russula Pers. has been recently receiving more attention in Brazil in the last few years. There are 17 species reported from Brazil, in the States of Amazonas, Paraná, Pernambuco, Rio Grande do Sul, Rondônia and São Paulo (Sá et al. 2013). In northeast Brazil, records were performed in the State of Pernambuco with $R$. batistae Singer, $R$. metachromatica ssp. notholeuca nom. inval., $R$. pluvialis Singer and R. ominileuca Sá \& Wartchow (Singer 1955, Singer et al. 1983, Sá \& Wartchow 2016). Here we report an interesting finding of a striking Russula, $R$. rubropunctatissima, previously described from French Guyana and now from Pernambuco State, Northeast Brazil.

\section{Materials \& Methods}

Data about the collection site and methodology of microscopic analysis were already briefly described by Sá \& Wartchow (2016). Color codes follow Kornerup \& Wanscher (1978). The material examined is deposited at UFRN-Fungos (Thiers, continuously updated).

\section{Results}

Russula rubropunctatissima Cheype \& E. Campo, Bull. Soc. Mycol. Fr. 128: 128. 2012. Figs 1-9 Basidiomata small, gregarious. Pileus $12-45 \mathrm{~mm}$ in diam., depressed, reddish brown (8D8), pellis dry, smooth at the center to wrinkled toward the margin with granules reddish brown and with concentric lines; margin smooth, decurved to straight; context up to $3 \mathrm{~mm}$ thick, pale cream, unchanging. Lamellae adnate, crowded, cream (4A3) with some brownish (6D8) spots, edge 
smooth and entire, repeatedly dichotomously bifurcating with different lengths. Stipe 10-38 × 4-8 $\mathrm{mm}$, central, subequal sometimes slightly narrowing downward, reddish brown (9F8), breaking into conspicuous concolorous granules over all lengths; context pale cream, unchanging, apparently hollow. Latex absent.

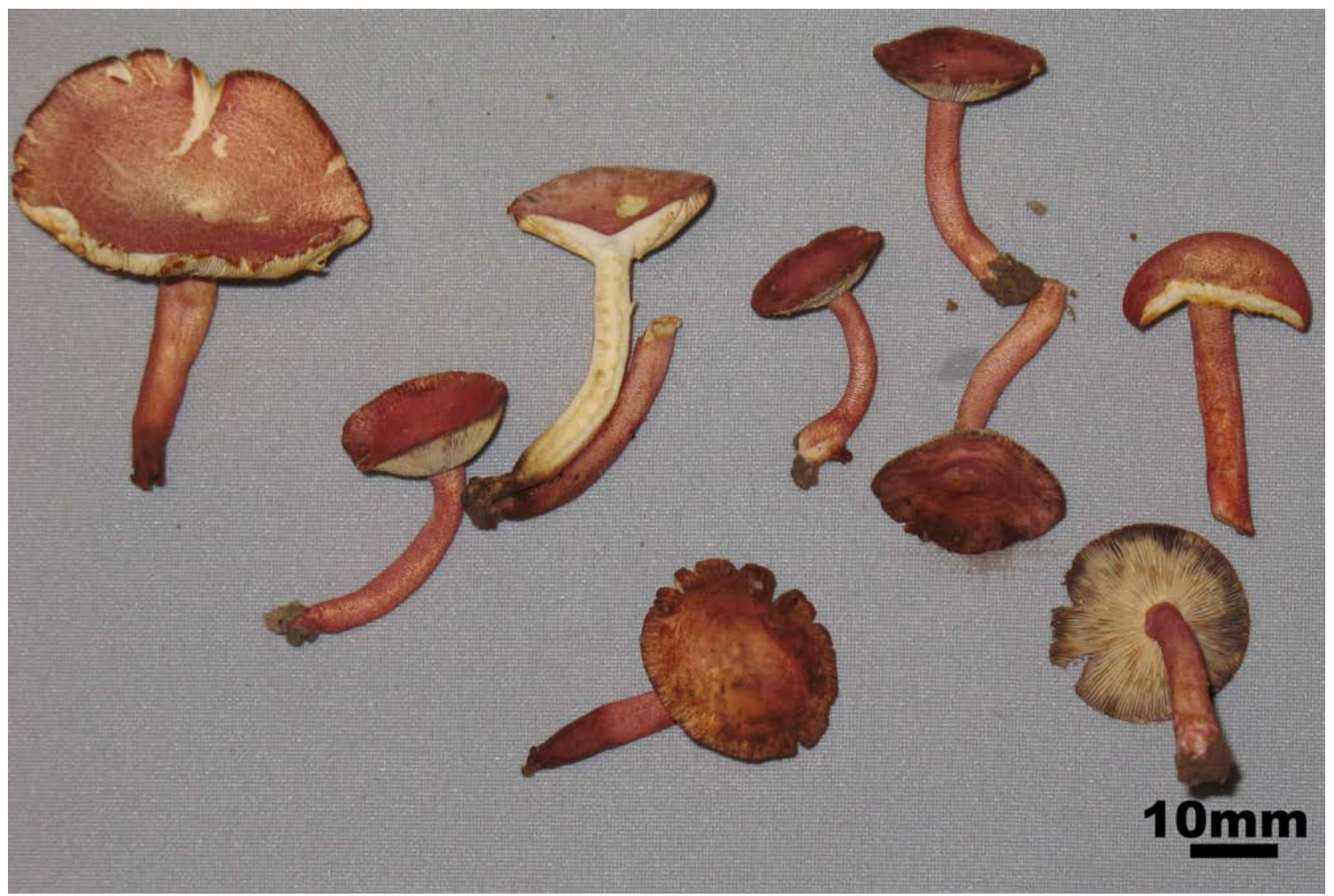

Fig. 1 - Russula rubropunctatissima. Basidiomes.

Basidiospores 4.6-6.1 × (4.1-)5.1-5.6 $\mu \mathrm{m}(\mathrm{L}=5.5 \mu \mathrm{m}, \mathrm{W}=4.9 \mu \mathrm{m}, \mathrm{Q}=1.00-1.22(-1.25)$, $\mathrm{Qm}=1.12$ ), globose to broadly ellipsoid; ornamentation amyloid, with irregular warts up to $0.3 \mu \mathrm{m}$ high, conic and isolated. Basidia 22-36 × 4-8 $\mu \mathrm{m}$, clavate, 4 sterigmata 2-3 $\mu \mathrm{m}$ wide. Lamella edge sterile, marginal cells 15-16 $\times 4-5 \mu \mathrm{m}$, clavate, thin-walled and hyaline in KOH3\%. Macropleurocystidia abundant, 60-90 × 6-13 $\mu \mathrm{m}$ wide, capitate, rarely cylindric and brownish in KOH3\%, thin-walled. Hymenophoral trama heteromerous, with abundant isodiametric cells 11-33 $\times 8-22 \mu \mathrm{m}$ and hyphae with 2-3 $\mu \mathrm{m}$ diam. Subhymenium with oleiferous hypheae frequent 6.5-8

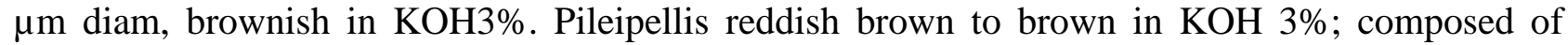
abundant interwoven and radically orientated hyphae 2-10 $\mu \mathrm{m}$ wide $\mu \mathrm{m}$, sphaerocysts $15-38 \times 15-$ $35 \mu \mathrm{m}$ at the base of the dertamocystidia; epicutis with abundant macrodermatocystidia 25-68 $\times 7$ $13 \mu \mathrm{m}$, capitate, fusoid and cylindric, some with incrustations in sulfovanilin, thin-walled; subcutis with abundant and large dermatocystidia 41-82 × 7-14 $\mu \mathrm{m}$, rarely ascending, without incrustations in sulvovanilin and reddish brown in $\mathrm{KOH} \mathrm{3 \% .} \mathrm{Stipitipellis} \mathrm{similar} \mathrm{to} \mathrm{pileipellis} \mathrm{in} \mathrm{structure,} \mathrm{with}$ caulocystidia up to $40-75 \times 8-13 \mu \mathrm{m}$, capitate to fusoid and cylindric, with incrustations in sulvovanilin and reddish brown in $\mathrm{KOH} \mathrm{3 \% ,} \mathrm{thin-walled.} \mathrm{Clamp} \mathrm{connections} \mathrm{absent.}$

Known distribution - French Guiana and Pernambuco, northeast Brazil. Duque Barbosa (2016) reported in his unpublished dissertation this species from Santa Catarina in South Brazil.

Material examined - Brazil, Pernambuco, Caruaru, Serra dos Cavalos, Parque Municipal João Vasconcelos Sobrinho (08 $21^{\prime} 43^{\prime \prime}$ S, 36 $02^{\prime} 10^{\prime \prime}$ W), 859 m alt., 17.III.2009, V.R.M. Coimbra s.n. (UFRN-Fungos 2180). 


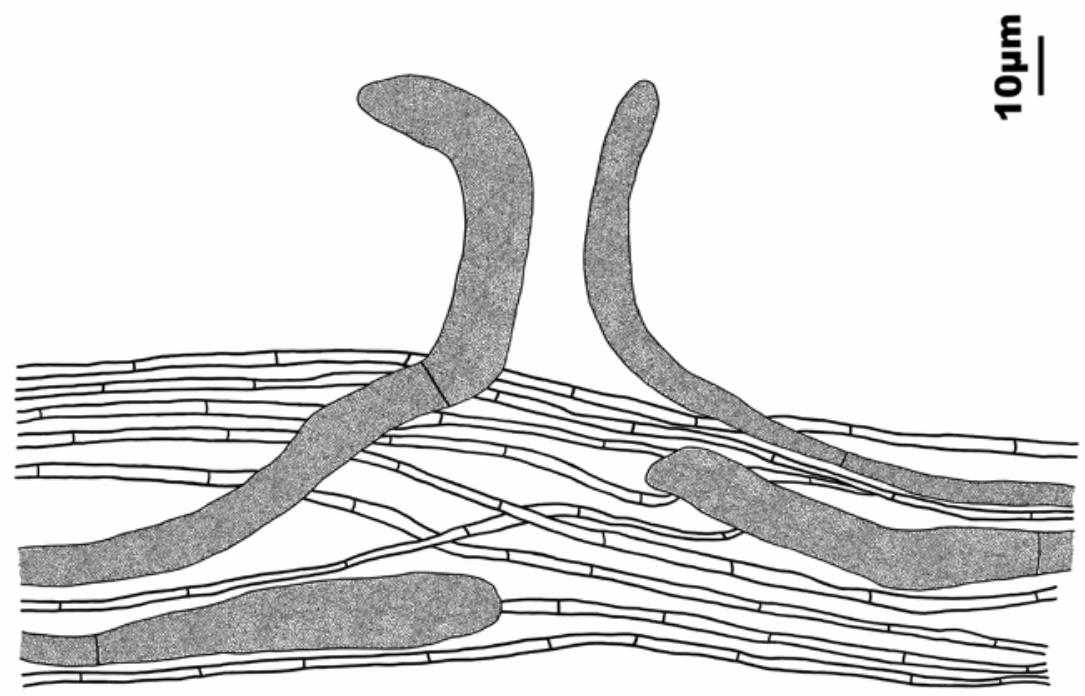

Fig. 2 - Russula rubropunctatissima. Detail of the subcutis and dematocystidia.

\section{Discussion}

Russula rubropunctatissima is characterized by the reddish brown pileus, smooth at centre to wrinkled toward the margin; basidiospores 4.6-6.1 × (4.1-)5.1-5.6 $\mu \mathrm{m}$ (excluding ornamentation), globose to broadly ellipsoid, amyloid, verrucose ornamentation, with warts up to $0.3 \mu \mathrm{m}$ high, isolated; pileipellis cutis-like, composed of abundant radially oriented hyphae 2-10 $\mu \mathrm{m}$ wide $\mu \mathrm{m}$; dermatocystidia 25-68 × 7-13 $\mu \mathrm{m}$, abundant, fusoid to cylindric, with incrustations in sulfovanilin and thin-walled.

As previously reported by Cheype \& Campo (2012) in the protologue of $R$. rubropunctatissima from French Guiana, this species is placed in the subsect. Pluviales Singer by the presence of macrodermatocystidia and the granules in the pileus and stipe. But this subsection is also characterized by the species with purple or violaceus pileus and basidiospores with isolate ornamentations. What makes $R$. rubropunctatissima very different from the two others species of this subsection, $R$. pluviales Singer and $R$. leguminosarum Singer that have lilac to purple pileus (Singer et al. 1983, Cheype \& Campo 2012), is the reddish pileus. In addition, $R$. pluvialis from Amazonas and Pernambuco differs in the purple discoloring fuliginous-sepia pileus, purple to similar color stipe (Singer et al. 1983) and larger basidiospores $7.01 \times 5.82 \mu \mathrm{m}$ (Buyck 1988); Russula legumninosarum Singer differs in the lilac-violet or dirty violet pileus, white stipe (Singer et al. 1983) and also larger basidiospores $8.03 \times 7.16 \mu \mathrm{m}$ (Buyck 1988).

They considered $R$. rubropunctatissima in subsect. Pluviales and argued that it should be more studies of molecular phylogeny (Cheype \& Campo 2012). In our case we tried to extract DNA from the species, but because of contamination of the samples it was unsuccessful.

Cheype \& Campo (2012) also discussed that the subsect. Pluviales belongs to the section Pelliculariae R. Heim, that regroup the little fleshy Russulas with acute pileus margin and wrinkled-grown surface in the adult state, and cream spore print. In this section there are two species with reddish pileus, $R$. carmesina R. Heim and R. pseudocarmesina Buyck (Buyck 1994). Russula carmesina differs by larger ornamentation with warts up to $1.5-2 \mu \mathrm{m}$ high and connected by fine lines in the spores and the structure of the pileipellis, while $R$. pseudocarmesina differs rubropunctatissima by the larger ornamentation with conic warts up to $2-2.5 \mu \mathrm{m}$ high in the spores connected by fine lines and the structure of the pileipellis (Buyck 1994). However, due the nature of the pileipellis structure as mentioned above, they belong to subsect. Pseudoepitheliosinae Buyck (Buyck 1990, 1992). 

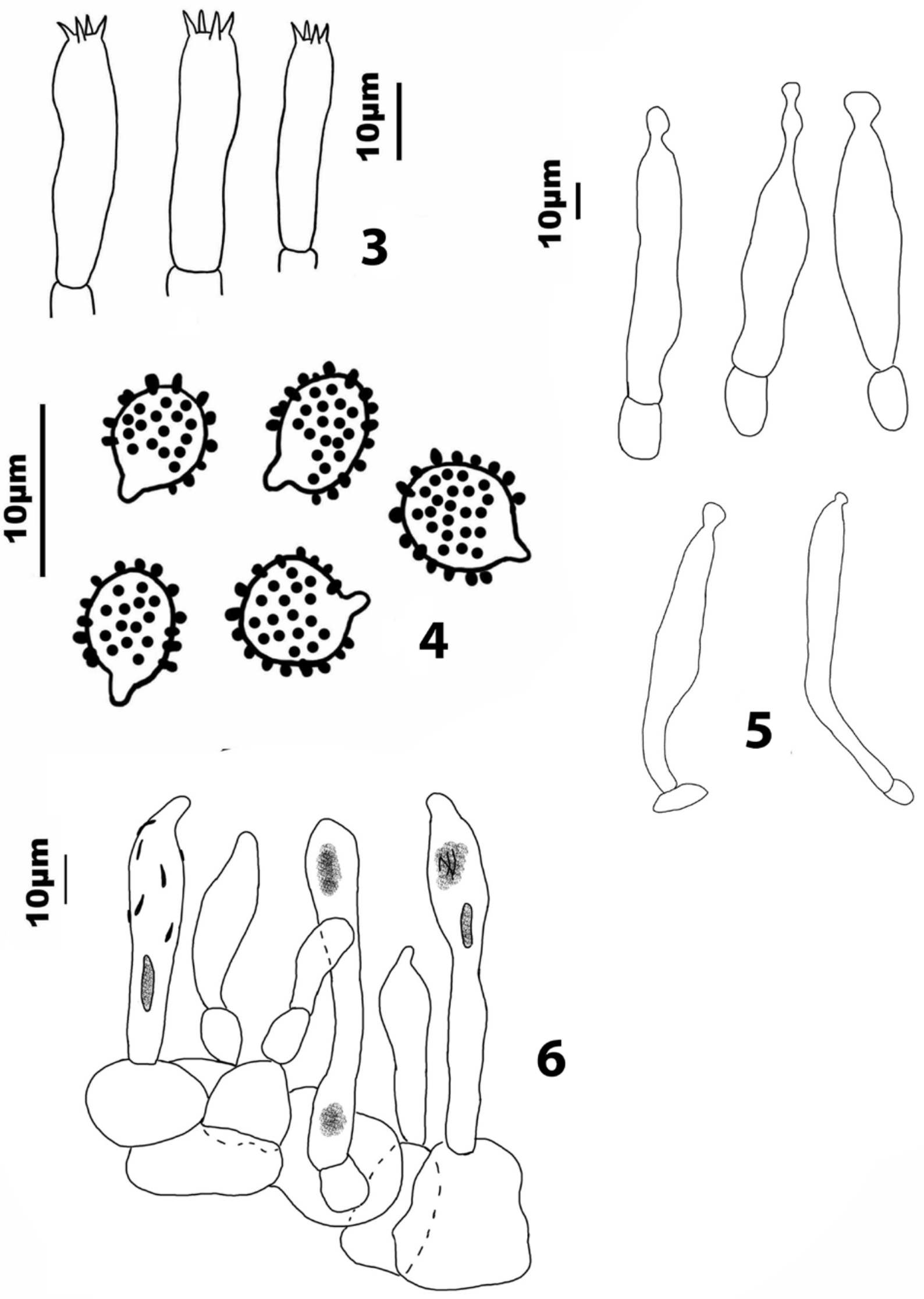

Figs 3-6 - Russula rubropunctatissima. 3 Basidia. 4 Basidiospores. 5 Pleurocystidia. 6 Detail of pileipellis with macrodermatocystidia. 


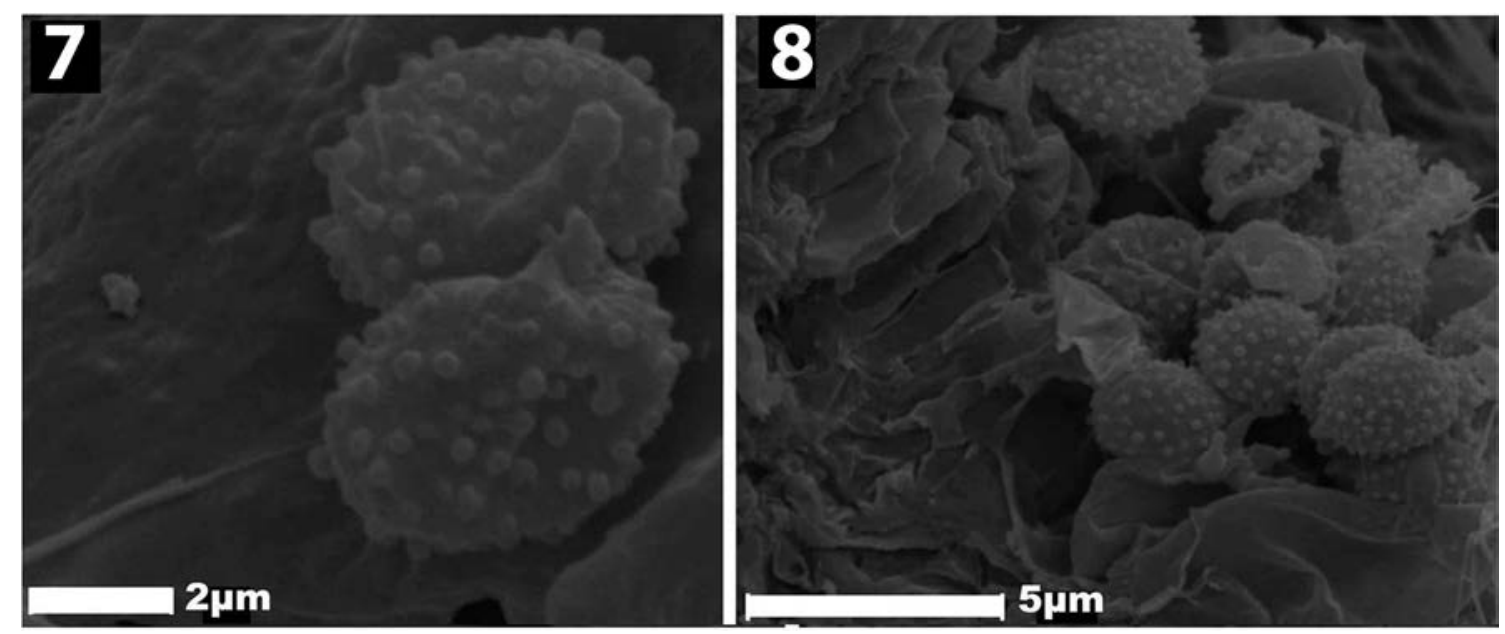

Figs 7-8 - Russula rubropunctatissima. 8 SEM images of the detail of two basidiospores. 9 SEM images of the basidiospores.

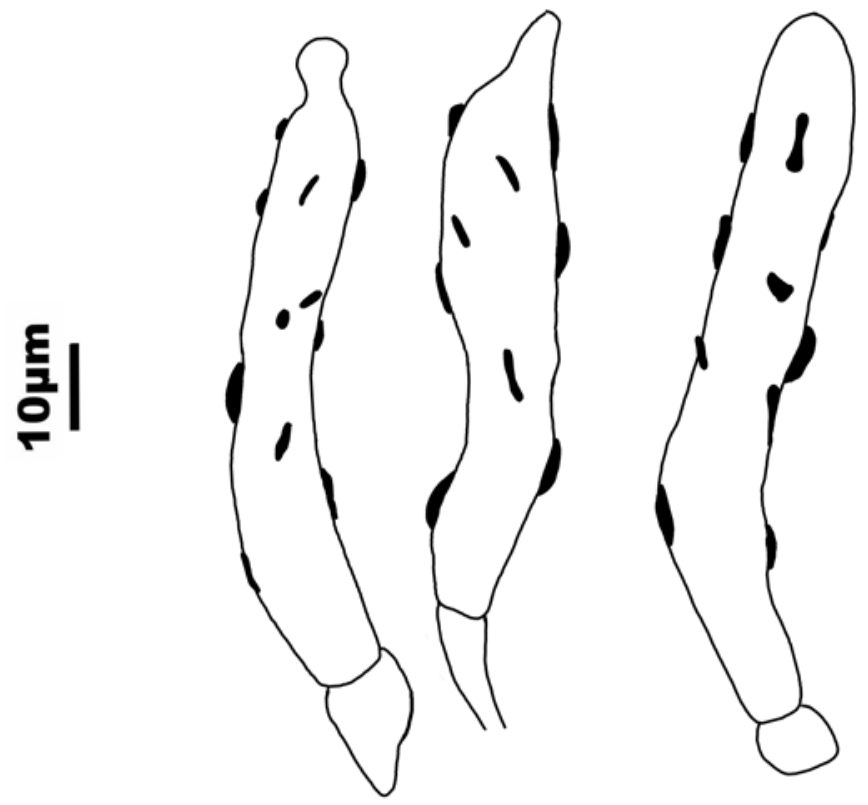

Fig. 9 - Russula rubropunctatissima. Detail of the caulocystidia.

\section{Acknowledgements}

The authors wish thank 'Conselho Nacional de Desenvolvimento Científico e Tecnológico' (CNPq) for providing funds for the 'Programa de Pesquisa em Biodiversidade' (PPBio) and 'Programa de Capacitação em Taxonomia' (PROTAX). 'Coordenação de Aperfeiçoamento de Pessoal de Nível Superior' (CAPES) is also acknowledged for provided scholarship to MCAS. We also thanks to Dr. Maria Regina Barbosa and TAXON laboratory for the use of study and facilities

\section{References}

Buyck B. 1988 - Étude microscopique de specimens types de Russules tropicales de la sous-section Pluviales. Mycotaxon 33, 71-80.

Buyck B. 1990 - New taxa of tropical Russulae: Pseudoepitheliosinae subsect. Nov. Mycotaxon 39, 317-327. 
Buyck B. 1992 - Checklist of tropical Russulaceae and their type specimen. Russulales News 1, 199.

Buyck B. 1994 - Russula II. Flore Illustree des Champignons d'Afrique Centrale 16, 409-539, figs. 258-351, pl. 69-87.

Cheype JL, Campo E. 2012 - Russula rubropunctatissima Cheype \& E. Campo une nouvelle russule découverte em Guyane Française. Bulletin Trimestriél de la Société Mycologique de France 128, 127-135.

Duque Barbosa JA. 2016 - Análise filogenética de Russula Pers. (Russulaceae, Russulales: Agaricomycetes). Master Dissertation, Universidade Federal de Santa Catarina, Florianópolis.

Kornerup A, Wanscher JH. 1978 - Methuen Handbook of Colour. $3^{\text {rd }}$ ed. Eyre Methuen, London.

Sá MCA, Wartchow F. 2016 - Russula omnileuca, a new species from Pernambuco, Brazil. Sydowia 68, 63-68.

Sá MCA, Baseia IG, Wartchow F. 2013 - Checklist of Russulaceae from Brazil. Mycotaxon 125, 303.

Singer R. 1955 - New species of Agaricales from Pernambuco. Anais da Sociedade de Biologia de Pernambuco 13, 225-229.

Singer R, Araújo I, Ivory MH. 1983 - The ectotrophically mycorrhizal Fungi of the Neotropical Lowlands, especially Central Amazonia. Beihefte zur Nova Hedwigia 77, 1-362.

Thiers B. [continuously updated] - Index Herbariorum: A global directory of public herbaria and associated staff. - New York Botanical Garden's Virtual Herbarium. http://sweetgum.nybg.org/ih/ (accessed 20 January 2018) 